


\section{Historic, archived document}

Do not assume content reflects current scientific knowledge, policies, or practices 



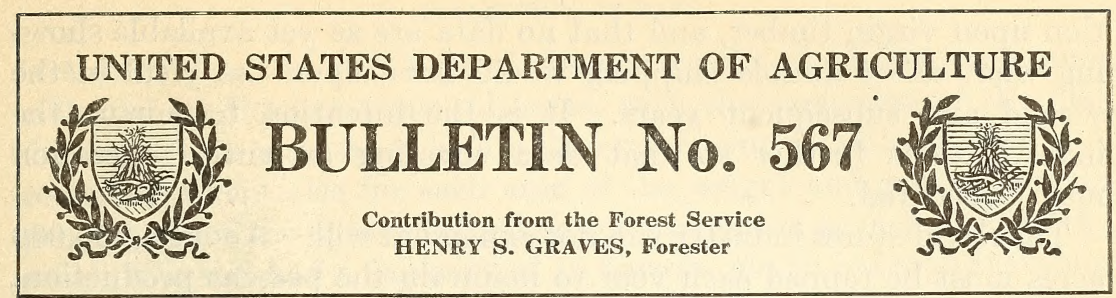

Washington, D. C.

PROFESSIONAL PAPER

October 2, 1917

\title{
INCREASED YIELD OF TURPENTINE AND ROSIN FROM DOUBLE CHIPPING.
}

\author{
By A. W. Schorger, Chemist in Forest Products, and R. L. Petrigrew, \\ Assistant Engineer in Forest Products.
}

\section{CONTENTS.}

\begin{tabular}{|c|c|c|}
\hline \multicolumn{2}{|c|}{ Page. } & Page. \\
\hline More naval stores from the same tree........ & 1 & Practicability of double chipping........... \\
\hline 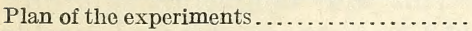 & 2 & Returns from double chipping, in dollars \\
\hline Yields.......................... & 4 & 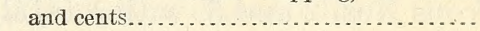 \\
\hline Effect of double chipping on the trees... & 6 & Summary \\
\hline
\end{tabular}

\section{MORE NAVAL STORES FROM THE SAME TREE.}

Naval-stores operators have the chance to get 31 per cent more turpentine and 36 per cent more rosin from their trees by increasing the number of chippings during a season. This has been determined by actual experiments made by the Forest Service on a tract in Mississippi, the results of which are presented in this bulletin. Briefly, the method that gives the increased yields is to chip twice a week instead of once. At the same time, the streaks are cut only one-fourth inch high instead of one-half inch, the present standard practice. The faces, therefore, are no higher at the end of the season than when they are chipped once a week.

Double chipping, of course, entails extra expense, but this is much more than off'set by increased returns. With all additional expenses taken into account, and in the light of present prices, double chipping ought to increase the net profits from a crop (10,000 faces) by about $\$ 450$. This means an increase in net profits from a 50-crop operation of about $\$ 22,000$.

While the experiments reported in this bulletin actually show a large increase in yields and revenue as a result of double chipping, it must be borne in mind that they cover only the first year's opera$99163^{\circ}-$ Bull. $567-17$ 
tion upon virgin timber, and that no data are as yet available showing what effect double chipping would have upon the yield in the second and subsequent years. It is the intention to pursue the investigations further so that data covering an entire operation may be secured.

The naval-stores industry can not expand at will. About 5,000,000 acres must be tapped each year to maintain the present production. In the same period lumbering removes the trees from about $1,000,000$ acres of virgin longleaf and slash pine, so the available field of operation is growing steadily smaller. "More naval stores from the same tree" must be the watchword of the industry if it is to meet the probable demand for turpentine and rosin without crippling itself for the future.

\section{PLAN OF THE EXPERIMENTS.}

The chipping was done on the holdings of a lumber company at Columbia, Miss. Three experimental areas were devoted to standard, narrow, and double chipping, respectively.

\section{STANDARD CHIPPING.}

Crops Nos. 2 and 5, with a total of 6,153 cups, were chipped weekly with a No. 2 hack. The depth of the streak varied from one-half to three-fourths inch. In order that the chipping might conform as nearly as possible to that prevailing on the place, no supervision was exercised beyond recording the data.

\section{NARROW CHIPPING.}

The area selected for narrow chipping consisted of all of crop No. 4 and one drift of crop No. 3, with a total of 6;881 faces. Four standard streaks had already been made on this area before the experiments were started. During the remainder of the season a streak about one-fourth inch high and of the same depth as the standard was cut every week. This insured that, at the end of the season, the faces would be approximately one-half the height of the standard. At first a specially constructed hack with a $\frac{3}{8}$-inch bill opening was used, but later was abandoned because it broke too easily. After that the chipping was done with either a No. 00 or No. 1 hack.

DOUBLE CHIPPING.

Five drifts of crop No. 3, totaling 3,107 faces, were used for double chipping. This area also had received four standard streaks at the beginning of the seson. The chipping was done in the same manner as the narrow chipping, except that two streaks were made per week, so that at the end of the season the faces would be of the same height as the standard faces. Chipping was done at intervals of three days. A drift chipped on Monday, for example, was chipped again on Thursday. 


\section{COLLECTION OF DATA.}

A careful record was kept of the net weight of all the crude gum collected on the experimental areas, with the exception of the first dipping which was made before the experiment could be started. A record was kept also for each area of the weight and grades of rosin produced and the number of gallons of turpentine as measured at the still. The still had a capacity of 10 barrels, but in order to maintain uniform conditions it was often necessary to hold over several barrels of gum until the next dipping before distilling.

The "scrape" from each plot was all collected at one time, but in distilling it 12 or 13 barrels formed the unit charge. What was left over was weighed as a basis for calculating the amount of turpentine and rosin represented by all the scrape, assuming the proportion of turpentine and rosin and the grade of rosin to be the same as in the case of the charge distilled. The same method of calculation was employed on a few barrels of "dip" remaining over at the end of the season. In this case the proportion of turpentine and rosin was assumed to be the same as that obtained from the last dipping. This dipping contained less turpentine than the average for the season, owing to the presence of considerable scrape cleaned from the faces and aprons.

At the beginning of the season, before the experiment proper had started, nine, nine, and four barrels of crude gum had been dipped from the standard, narrow, and double plots, respectively. No record was kept except as to the number of barrels, so an estimate was made of the weight of gum and the yield of rosin and turpentine based on the average weights and yields of the gum from the first few charges immediately following.

On the standard, and especially on the double-chipping areas, the gum from a considerable number of faces was lost during a large part of the season from causes ordinarily avoidable. The camp and still were located in the double-chipping area and near the standard area. Some of the trees were cut to make room for additional buildings, some were cut for structural timbers, while others had to be abandoned for various reasons. At the end of the season a careful count of these faces was made and the loss estimated according to the height of the face. Two faces that had been chipped for onehalf the season were considered as one face lost for the entire season. The number of faces lost in this manner was subtracted from the original count in each plot, and the number thus obtained was taken as the actual number of faces upon which to base the yields.

A number of faces in each plot were not chipped a portion or all of the season for causes that might be met with in any operation. These included faces in out-of-the-way corners among undergrowth, and missed intentionally or otherwise by the chipper; those along 
streams made inaccessible by débris from freshets; trees blown down or struck by lightning; those where cups had been hung on the dead side of the tree; and faces that "dried out" soon after chipping. A count was made of such faces, including every one that had dried out to any extent and those on trees that had died from unknown causes. The portions of the season lost by these faces are given in Table 1. The yields for the season have not been corrected for such losses, since these must be accepted in all operations.

TABLE 1.-Faces lost on account of "dry peaks," "dry faces," trees dying, faces not being chipped, and various causes not avoidable in turpentine operations.

\begin{tabular}{|c|c|c|c|c|c|c|c|c|c|}
\hline \multirow{2}{*}{ Plot. } & \multirow{2}{*}{$\begin{array}{l}\text { Actual } \\
\text { faces } \\
\text { worked. }\end{array}$} & \multicolumn{4}{|c|}{ Portion of season lost- } & \multicolumn{4}{|c|}{$\begin{array}{l}\text { Portion of season lost by faces } \\
\text { on trees dying for reasons not } \\
\text { apparent- }\end{array}$} \\
\hline & & 0 to $\frac{x}{4}$. & $\frac{1}{4}$ to $\frac{1}{2}$. & $\frac{1}{2}$ to $\frac{3}{4}$. & 3 to all. & 0 to $\frac{2}{4}$. & $\frac{1}{4}$ to $\frac{1}{2}$. & $\frac{1}{2}$ to $\frac{3}{4}$. & $\frac{3}{4}$ to all. \\
\hline $\begin{array}{l}\text { Standard chippin } \\
\text { Narrow chipping. } \\
\text { Double chipping. }\end{array}$ & $\begin{array}{l}6,142 \\
6,881 \\
3,049\end{array}$ & $\begin{array}{r}151 \\
149 \\
90\end{array}$ & $\begin{array}{l}33 \\
29 \\
37\end{array}$ & $\begin{array}{l}17 \\
16 \\
16\end{array}$ & $\begin{array}{r}2 \\
11 \\
13\end{array}$ & $\begin{array}{l}2 \\
3 \\
2\end{array}$ & $\begin{array}{r}20 \\
5 \\
4\end{array}$ & $\begin{array}{r}8 \\
11 \\
0\end{array}$ & $\begin{array}{l}2 \\
0 \\
3\end{array}$ \\
\hline
\end{tabular}

\section{YIELDS.}

The actual yields obtained are given in Table 2. In this table, as well as throughout the bulletin, the weight of the rosin includes the weight of the barrel. Usually in selling rosin no deduction is made from the gross weight. Since each of the three areas had a different number of faces, in Table 3, for purposes of comparison, the figures are reduced to a basis of 10,000 faces, or one crop, which usually is taken as the standard unit in the naval-stores industry.

Little importance should be attached to the difference in the grades and in the amount of each grade of rosin produced by the different areas, since the grades were lowered by carrying over a few barrels of gum from one charge to the next, as explained. The deterioration on standing was shown by a simple experiment with gum from the standard area.

Sixteen barrels of this gum were held over for nearly a month during the middle of the season. At the time this gum was collected, that from the entire place produced rosin which graded about 60 per cent $\mathrm{W} G$ and $N$. The treatment of this gum in the woods and at the still was similar to that given the 16 barrels held over, except for the time elapsing between collection and distillation. All the rosin from these 16 barrels graded M at least one grade lower than that from the fresh gum. The total effect of the stored gum on the grades of rosin could not be determined, so that in considering the economic side of the experiments a nominal uniform price per barrel will be selected. 


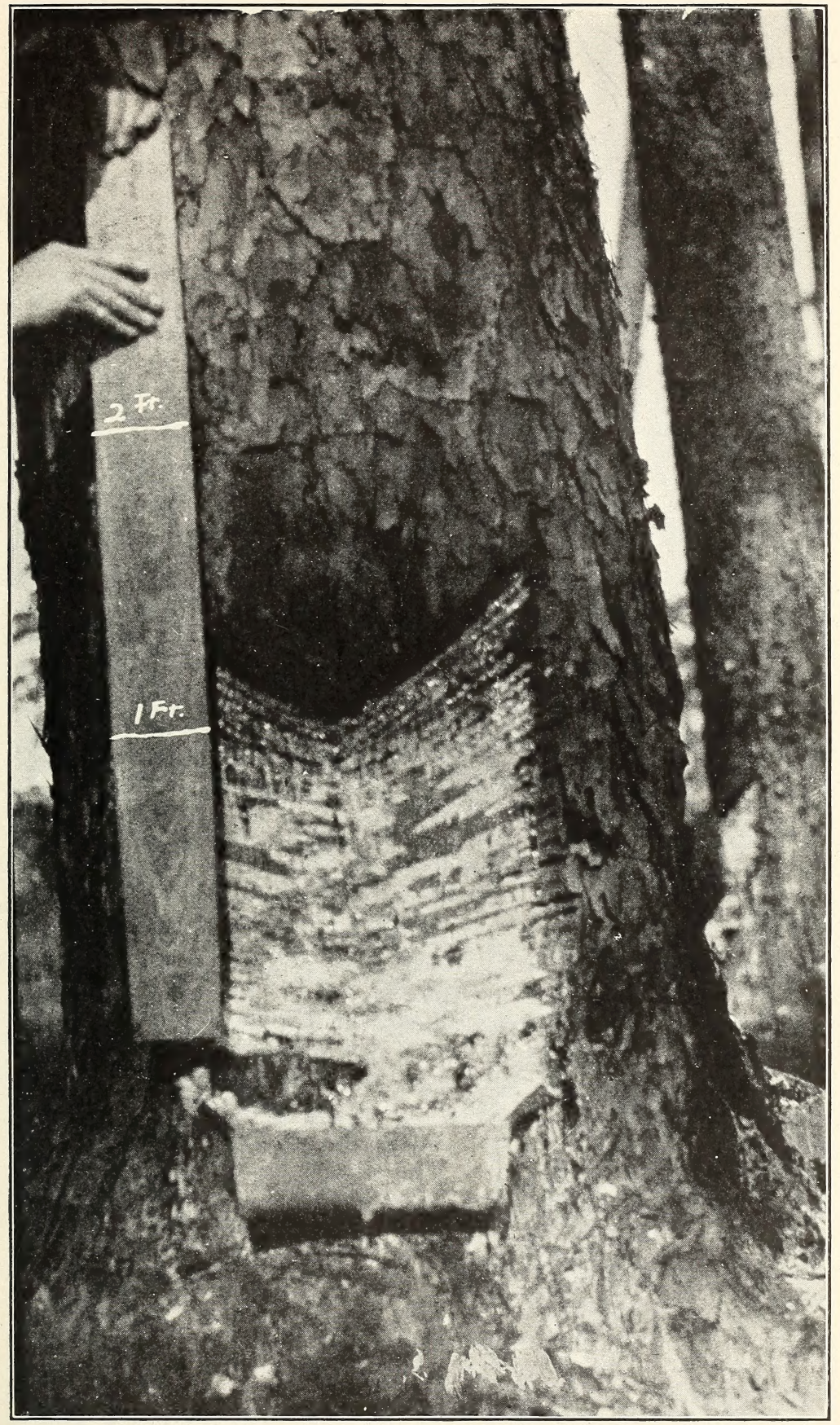

F-1-S. \& P

Narrow Chipped faces are only half as High at the End of the Season AS WHEN THE STREAKS ARE CUT ONE-HALF INCH. 


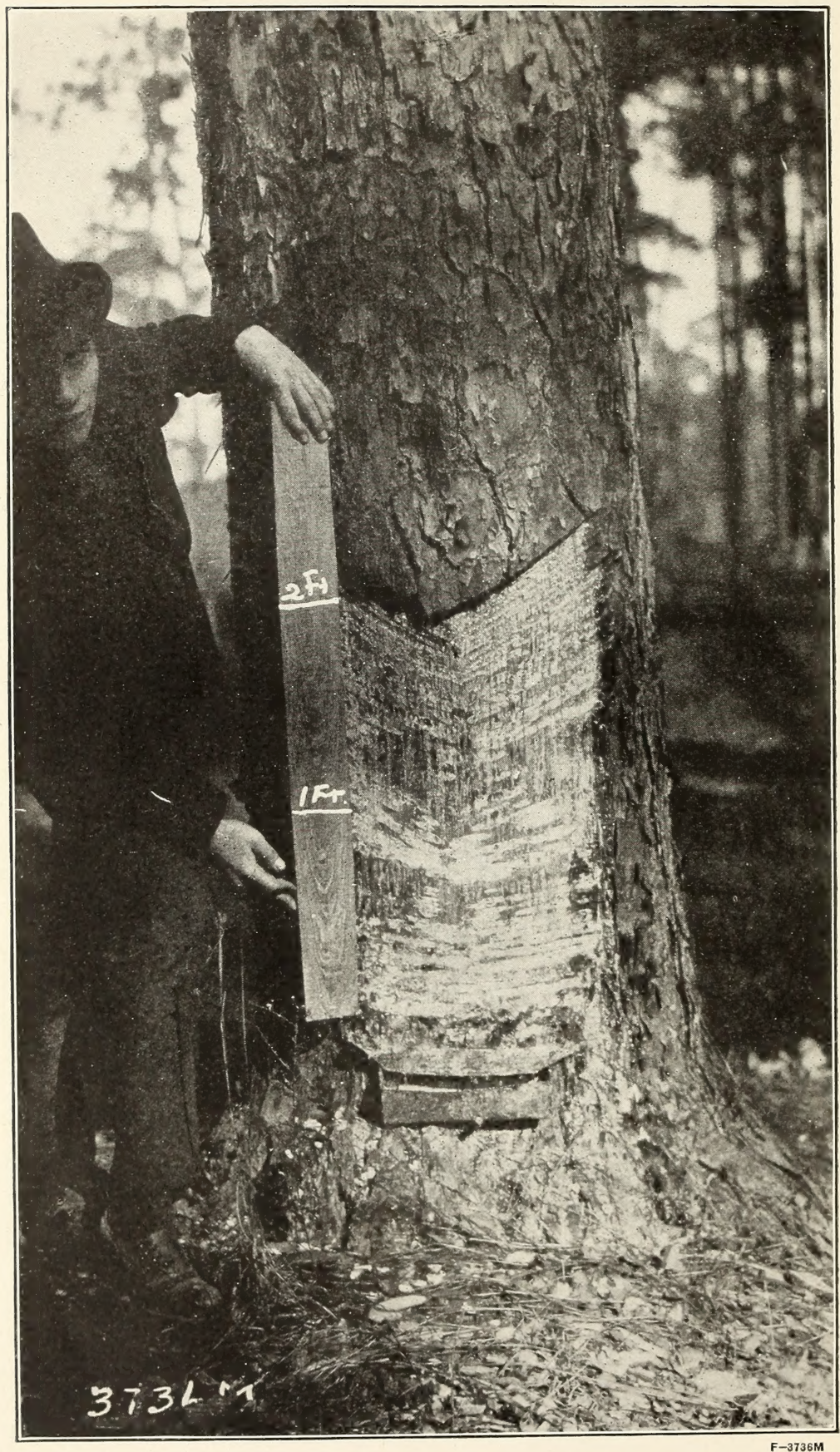


The scrape was distilled the day following collection, but even in this case a comparison of the grades of rosin may be erroneous. At the time of distillation the price of turpentine was high, while the higher grades of rosin differed little in value, so that the quality of the rosin sometimes was sacrificed for a higher yield of turpentine.

TABLE 2.- Yield of crude gum, scrape, rosin, and turpentine from experimental plots.

\begin{tabular}{|c|c|c|c|c|c|c|c|c|c|c|c|}
\hline \multirow{2}{*}{$\begin{array}{c}\text { Plot. } \\
\text { Standard chipping }\end{array}$} & \multirow{2}{*}{$\begin{array}{l}\text { Num- } \\
\text { ber of } \\
\text { cups. }\end{array}$} & \multirow{3}{*}{$\begin{array}{c}\begin{array}{c}\text { Yield } \\
\text { of } \\
\text { gum. }\end{array} \\
\begin{array}{c}L b s . \\
63,926\end{array}\end{array}$} & \multirow{2}{*}{$\begin{array}{c}\text { Tur- } \\
\text { pen- } \\
\text { tine } \\
\text { from } \\
\text { gum. } \\
\text { Gal. } \\
1,709.5\end{array}$} & \multicolumn{2}{|c|}{$\begin{array}{l}\text { Rosin from } \\
\text { gum. }\end{array}$} & \multirow{2}{*}{$\begin{array}{c}\begin{array}{c}\text { Yield } \\
\text { of } \\
\text { scrape. }\end{array} \\
\begin{array}{c}\text { Lbs. } \\
16,545\end{array}\end{array}$} & \multirow{2}{*}{$\begin{array}{c}\text { Tur- } \\
\text { pen- } \\
\text { tine } \\
\text { from } \\
\text { scrape. } \\
\text { Gal. } \\
293\end{array}$} & \multicolumn{2}{|c|}{$\begin{array}{c}\text { Rosin from } \\
\text { scrape. }\end{array}$} & \multirow{2}{*}{$\begin{array}{c}\text { Total } \\
\text { rosin. } \\
\begin{array}{c}\text { Lbs. } \\
64,822\end{array}\end{array}$} & \multirow{2}{*}{$\begin{array}{c}\text { Total } \\
\text { tur- } \\
\text { pen- } \\
\text { tine. } \\
\text { Gal. } \\
2,002.5\end{array}$} \\
\hline & & & & \begin{tabular}{r}
\multicolumn{1}{c}{$L b s_{.}$} \\
19,624 \\
6,882 \\
12,941 \\
2,480 \\
8,770
\end{tabular} & $\begin{array}{c}\text { Grade. } \\
\text { WW } \\
\text { WG } \\
\underset{\text { M }}{\mathrm{K}} \\
\underset{\mathbf{I}}{\mathrm{W}}\end{array}$ & & & $\begin{array}{l}\text { Lbs. } \\
3,633 \\
7,164 \\
3,328\end{array}$ & $\begin{array}{c}\text { Grade. } \\
\mathbf{N} \\
\mathbf{M} \\
\mathbf{K}\end{array}$ & & \\
\hline Total.... & & & & 50,697 & & & & 14,125 & & & \\
\hline Narrow chipping. & 6,881 & 61,062 & 1,618 & $\begin{array}{r}14,496 \\
5,755 \\
7,422 \\
6,430 \\
5,661 \\
8,460\end{array}$ & $\begin{array}{l}\text { WW } \\
\text { WG } \\
N \\
M \\
\text { K } \\
\text { I }\end{array}$ & 14,515 & 235 & $\begin{array}{l}2,970 \\
3,485 \\
2,970 \\
2,225\end{array}$ & $\begin{array}{l}\frac{N}{M} \\
\frac{K}{H}\end{array}$ & 59,874 & 1,853 \\
\hline Total... & & & & 48,224 & & & & 11,650 & & & \\
\hline Double chipping. . & 3,049 & 42,687 & 1,092 & $\begin{array}{r}10,652 \\
2,860 \\
3,600 \\
3,405 \\
2,550 \\
3,668 \\
5,439\end{array}$ & $\begin{array}{l}\text { WW } \\
\text { WG } \\
N \\
M \\
\text { K } \\
\text { I } \\
\text { H }\end{array}$ & 13,615 & 209 & $\begin{array}{r}1,165 \\
10,427\end{array}$ & $\begin{array}{l}\mathrm{N} \\
\mathrm{M}\end{array}$ & 43,766 & 1,301 \\
\hline Total... & & & & 32,174 & & & & 11,592 & & & \\
\hline
\end{tabular}

TABLE 3.- Yield of crude gum, scrape, rosin, and turpentine per crop of 10,000 faces on each of the experimental plots.

\begin{tabular}{|c|c|c|c|c|c|c|c|c|c|c|}
\hline Plot. & $\begin{array}{l}\text { Yield } \\
\text { of } \\
\text { gum. }\end{array}$ & $\begin{array}{l}\text { Tur- } \\
\text { pen- } \\
\text { tine } \\
\text { from }\end{array}$ & \multicolumn{2}{|c|}{$\begin{array}{l}\text { Rosin from } \\
\text { gum. }\end{array}$} & $\begin{array}{c}\text { Yield } \\
\text { of } \\
\text { scrape. }\end{array}$ & $\begin{array}{l}\text { Tur- } \\
\text { pen- } \\
\text { tine } \\
\text { from }\end{array}$ & \multicolumn{2}{|c|}{$\begin{array}{l}\text { Rosin from } \\
\text { scrape. }\end{array}$} & $\begin{array}{l}\text { Total } \\
\text { rosin. }\end{array}$ & $\begin{array}{l}\text { Total } \\
\text { tur- } \\
\text { pen- } \\
\text { tine. }\end{array}$ \\
\hline Standard chipping. & \multirow[t]{2}{*}{$\begin{array}{c}L b s . \\
104,080\end{array}$} & \multirow[t]{2}{*}{$\begin{array}{l}\text { Gal. } \\
2,783\end{array}$} & $\begin{array}{r}\text { Lbs. } \\
31,951 \\
11,205 \\
21,070 \\
4,037 \\
14,279\end{array}$ & \multirow[t]{2}{*}{$\begin{array}{c}\text { Grade. } \\
\text { WW } \\
\text { WG } \\
\text { M } \\
\underset{\mathrm{K}}{\mathrm{I}}\end{array}$} & \multirow[t]{2}{*}{$\underset{26,936}{L b s .}$} & \multirow[t]{2}{*}{$\begin{array}{l}\text { Gal. } \\
\quad 477\end{array}$} & \begin{tabular}{r}
\multicolumn{1}{l}{$L b s_{.}$} \\
5,915 \\
11,664 \\
5,418
\end{tabular} & \multirow[t]{2}{*}{$\begin{array}{c}\text { Grade. } \\
\mathbf{N} \\
\mathbf{M} \\
\mathrm{K}\end{array}$} & \multirow[t]{2}{*}{$\underset{105,539}{L b s}$} & \multirow[t]{2}{*}{$\begin{array}{l}\text { Gal. } \\
3,260\end{array}$} \\
\hline Total........... & & & 82,542 & & & & 22,997 & & & \\
\hline Narrow chipping... & 88,740 & 2,351 & $\begin{array}{r}21,067 \\
8,364 \\
10,785 \\
9,345 \\
8,227 \\
12,294\end{array}$ & $\begin{array}{l}\text { WW } \\
\text { WG } \\
\text { N } \\
\text { M } \\
\text { K } \\
\text { I }\end{array}$ & 21,094 & 342 & $\begin{array}{l}4,316 \\
5,065 \\
4,316 \\
3,234\end{array}$ & $\begin{array}{l}\mathrm{N} \\
\mathbf{M} \\
\mathrm{K} \\
\mathrm{H}\end{array}$ & 87,014 & 2,693 \\
\hline Total.... & & & 70,082 & & & & 16,931 & & & \\
\hline Douible chipping... & 140,003 & 3,582 & $\begin{array}{r}34,936 \\
9,380 \\
11,807 \\
11,168 \\
8,363 \\
12,030 \\
17,839\end{array}$ & $\begin{array}{l}\text { WW } \\
\text { WG } \\
\mathbf{N} \\
\mathbf{M} \\
\mathbf{K} \\
\mathbf{T} \\
\mathrm{H}\end{array}$ & 44,654 & 685 & $\begin{array}{r}3,821 \\
34,198\end{array}$ & $\begin{array}{l}\mathrm{N} \\
\mathrm{M}\end{array}$ & 143,542 & 4,267 \\
\hline Total.... & & & 105,523 & & & & 38,019 & & & \\
\hline
\end{tabular}


In Table 4 the total quantities of turpentine and rosin obtained by narrow, double, and standard chipping are compared on a percentage basis. Double chipping increased the yields of turpentine and rosin 30.9 per cent and 36 per cent, respectively. The greater increase in rosin is due to the heavy yield of scrape. The yields of turpentine and rosin were decreased 17.4 per cent and 17.5 per cent, respectively, by narrow chipping. It will be noted, however, that the narrow faces are only about one-half the height of the standard or double faces. The comparative heights of the faces are shown in Plates I and II.

In Table 5 the yields have been arranged with respect to the height of face, the widths of all the faces being practically identical. On this basis the narrow chipping produced about 40 per cent more turpentine and rosin than the standard. Narrow chipping, however, would not be practical in the light of present prices for labor and timber leases.

TABLE 4.-Comparison of the yields per crop by the various methods of chipping.

\begin{tabular}{|c|c|c|c|c|}
\hline Plot. & $\begin{array}{l}\text { Yield of } \\
\text { turpen- } \\
\text { tine. }\end{array}$ & $\begin{array}{l}\text { Compared } \\
\text { with } \\
\text { standard. }\end{array}$ & $\begin{array}{l}\text { Yield of } \\
\text { rosin. }\end{array}$ & $\begin{array}{l}\text { Compared } \\
\text { with } \\
\text { standard. }\end{array}$ \\
\hline $\begin{array}{l}\text { Standard chipping..... } \\
\text { Narrow chipping....... } \\
\text { Double chipping........ }\end{array}$ & $\begin{array}{r}\text { Gallons. } \\
3,260 \\
2,693 \\
4,267\end{array}$ & $\begin{array}{c}\text { Per cent. } \\
100 \\
82.6 \\
130.9\end{array}$ & $\begin{array}{r}\text { Pounds. } \\
105,539 \\
87,014 \\
143,542\end{array}$ & $\begin{array}{c}\text { Per cent. } \\
100 \\
82.5 \\
136\end{array}$ \\
\hline
\end{tabular}

\section{EFFECT OF DOUBLE CHIPPING ON THE TREES.}

The effect that double chipping will have upon the timber during: subsequent years of operation must be considered. The same trees will be tapped during the coming season, and until the additional data are available the advisability of using the method over a period of years must remain in doubt. Some data in regard to the severity of the several methods, however, will be found in Table 2. By far the greater number of faces recorded in this table, especially those that had lost from 0 to $\frac{1}{4}$ the season, were "dry" faces. This condition has been the result of old or "doty" timber or the direct result of turpentining. In the standard chipping a total of 235 faces, or 38.3 per thousand, were affected. The narrow chipping contained 223 injured faces, or 32.4 per thousand, while the double chipping contained 165 , or 54 per thousand.

This would seem to indicate that double chipping is the severest and narrow chipping the least so. However, in the second part of Table 1, it will be noted that in the standard chipping there were 32 faces on trees that had died for no apparent reasons, equivalent to 5.2 faces per thousand. For the narrow and double chipping the 
figures are 2.8 and 2.9 per thousand, respectively. These trees may have died from tapping or from natural causes. If the dead faces were the result of turpentining, it would indicate that standard chipping was hardest on the timber, the double next, and the narrow easiest. It is logical to assume, however, that double chipping would be severer than the standard. Since most of the trees died early in the season, it is probable that method of chipping had little effect.

TABLE 5.-Comparative yields per crop with respect to height of face.

\begin{tabular}{|c|c|c|c|c|c|c|c|c|c|}
\hline \multirow[b]{2}{*}{ Plot. } & \multirow[b]{2}{*}{$\begin{array}{l}\text { Feight } \\
\text { of face. }\end{array}$} & \multirow{2}{*}{$\begin{array}{c}\text { Num- } \\
\text { ber of } \\
\text { streaks. }\end{array}$} & \multirow{2}{*}{$\begin{array}{c}\text { A ver- } \\
\text { age } \\
\text { height } \\
\text { of } \\
\text { streak. }\end{array}$} & \multicolumn{3}{|c|}{ Turpentine. } & \multicolumn{3}{|c|}{ Rosin. } \\
\hline & & & & $\begin{array}{l}\text { Total } \\
\text { yield. }\end{array}$ & $\begin{array}{c}\text { Per } \\
\text { inch } \\
\text { of } \\
\text { height. }\end{array}$ & Increase. & $\begin{array}{l}\text { Total } \\
\text { yield. }\end{array}$ & $\begin{array}{c}\text { Per } \\
\text { inch } \\
\text { of } \\
\text { height. }\end{array}$ & Increase. \\
\hline 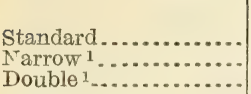 & $\begin{array}{r}\text { Inches. } \\
21.95 \\
12.85 \\
23.67\end{array}$ & $\begin{array}{l}38 \\
38 \\
70\end{array}$ & $\begin{array}{r}\text { Inches. } \\
0.58 \\
.34 \\
.34\end{array}$ & $\begin{array}{c}\text { Gallons. } \\
3,260 \\
2,693 \\
4,267\end{array}$ & $\begin{array}{r}\text { Gailons. } \\
148 \\
209 \\
180\end{array}$ & $\begin{array}{r}\text { Per cent. } \\
41.2 \\
21.6\end{array}$ & $\begin{array}{r}\text { Pounds. } \\
105,539 \\
87,014 \\
143,542\end{array}$ & $\begin{array}{r}\text { Pounds. } \\
4,808 \\
6,771 \\
6,064\end{array}$ & $\begin{array}{r}\text { Per cent. } \\
40.8 \\
26.1\end{array}$ \\
\hline
\end{tabular}

1 The narrow and double areas had four standard streaks before the experiment started. The height of the four streaks averaged 2.75 inches from 25 measurements. With this allowance, the streaks on the narrow and double areas averaged 0.30 and $0.32 \mathrm{inch}$, respectively. The corrected height for the double face is 22.20 inches and for the narrow face 11.38 inches.

\section{PRACTICABILITY OF DOUBLE CHIPPING.}

In the experiments the double chipping was done on exact schedule. Certain trees were chipped always on prescribed days of the week, except in a few instances when weather interfered. It is very improbable that an exact schedule could be maintained on a 50-crop place, but for practical purposes this would not be necessary. In the experiment the number of faces for double chipping was made small enough for the chipper to cover the ground easily on scheduled time. In practice each chipper would have about 4,000 faces. Since few chippers can handle more than this number in three days, it is improbable that the second streak would be applied too soon. It is expected that a streak would be missed occasionally, as this frequently happens with the present method of chipping. The idea is not to have a rigid schedule impossible to follow, but so far as possible to make two streaks per week where the old method requires one, these two streaks not to increase the height of the face more than the one standard streak. In every case, however, at least three days should elapse between streaks.

The chief problem would be to find a sufficient number of chippers. The smaller streak is not difficult to cut. More care is required in making it, but less effort is required to drive the hack through the wood. Standard No. 0 or No. 00 hacks were found to give the best results. 
TABLE 6.- Monthly rainfall and temperature during the season of 1916 at Columbia, Miss.

\begin{tabular}{|c|c|c|c|c|c|c|c|c|}
\hline Rainfall and temperature. & March. & April. & May. & June. & Juls. & $\begin{array}{l}\text { Au- } \\
\text { gust. }\end{array}$ & $\begin{array}{l}\text { Sep- } \\
\text { tem- } \\
\text { ber. }\end{array}$ & $\begin{array}{l}\text { Octo- } \\
\text { ber. }\end{array}$ \\
\hline \multirow{3}{*}{$\begin{array}{l}\text { Mean rainfall at Columbia.....inches. } \\
\text { Departure from normal at Colum- } \\
\text { bia......................................... } \\
\text { Mean temperature for Columbia.. }{ }^{\circ} \mathrm{F} . \\
\text { Mean temperature for the State for a } \\
\text { period of over } 10 \text { years.......... }{ }^{\circ} \mathrm{F} .\end{array}$} & 5.20 & 3.83 & 12.44 & 1.64 & 9.25 & 2.54 & 2.28 & 2.33 \\
\hline & $\frac{-.19}{60.2}$ & $\begin{array}{c}-2.24 \\
64.8\end{array}$ & $\begin{array}{c}+5.65 \\
75.3\end{array}$ & $\begin{array}{c}-3.21 \\
80.2\end{array}$ & $\begin{array}{c}+3.12 \\
82.6\end{array}$ & $\begin{array}{c}-1.63 \\
82.5\end{array}$ & $\begin{array}{c}-3.45 \\
75.6\end{array}$ & -.17 \\
\hline & 57.8 & 64.3 & 71.9 & 78.7 & 80.9 & 80.8 & 75.9 & 64.0 \\
\hline
\end{tabular}

The above data show that the season can not be considered as unusual in regard to either rainfall or temperature.

\section{RETURNS FROM DOUBLE CHIPPING IN DOLLARS AND CENTS.}

During the season of 1916 the price of turpentine varied from 36 to 50 cents per gallon, Savannah quotations. During the greater portion of the season turpentine was quoted at more than 40 cents, but at the still it sold at Sarannah quotations, less freight rates to this market. For the purposes of this report, 40 cents per gallon will be taken as the average price of turpentine for 1916.

Very little difference in price existed between the various grades of rosin during the season of 1916. Water-white and window-glass rosins were produced almost exclusively up to August 1, the prices ranging from $\$ 5.10$ to $\$ 6.60$ for WG and $\$ 5.20$ to $\$ 6.90$ for WW. After August 1, F, the lowest grade of rosin produced on the place, sold at from $\$ 6$ to $\$ 6.35$. In order to make a conservative estimate of the added returns, the average price of rosin at the still was assumed to be $\$ 5$ per barrel.

Upon this basis the increased yield from double chipping would show the following excess value per crop:

1.007 gallons increase in turpentine, at 40 cents per gallon............ $\$ 402.80$ $3 \varsigma .003$ pounds increase in rosin, at $\$ 5$ per barrel of 280 pounds.......... 678.50

Total.

$1,081.30$

From this amount should be subtracted the extra cost of operating under the new method. Besides the actual cost of the extra streaks, other expenses are entailed. On a 50-crop place it will be necessary to maintain from 55 to 60 extra men, requiring about 35 extra houses at $\$ 150$ each. Against the houses must be charged interest on the inrestment and a depreciation of about 30 per cent. There would also be needed an extra woodman at $\$ 900$ per year, and an extra "stiller" with a crew of four, requiring an expenditure of about $\$ 2,000$ per year. Numerous additional minor expenses will be found listed in Table 7 , in which the extra charges hare been reduced to the onecrop basis. 
These figures show that double chipping will increase the net profits per crop by about $\$ 450$.

Increase from additional yield. $\$ 1,081.30$

Extra cost of using new method. 631. 60

Net gain 449. 70

At present prices the total net gain from a 50-crop place would be about $\$ 22,000$.

Many of the large lumber companies tap their timber from two to three years before cutting. Frequently turpentining is barely a year ahead of cutting. It is in these cases that double chipping should be especially advantageous.

TABLE 7.-Added cost per crop of double chipping as conducted on the experimental area.

\begin{tabular}{|c|c|c|c|c|c|c|}
\hline Item. & $\begin{array}{c}\text { Number } \\
\text { on } \\
\text { double. }\end{array}$ & $\begin{array}{c}\text { Number } \\
\text { on } \\
\text { single. }\end{array}$ & Price. & $\begin{array}{l}\text { Cost per } \\
\text { crop on } \\
\text { double. }\end{array}$ & $\begin{array}{l}\text { Cost per } \\
\text { crop on } \\
\text { standard. }\end{array}$ & $\begin{array}{l}\text { Extra } \\
\text { cost per } \\
\text { crop on } \\
\text { double. }\end{array}$ \\
\hline 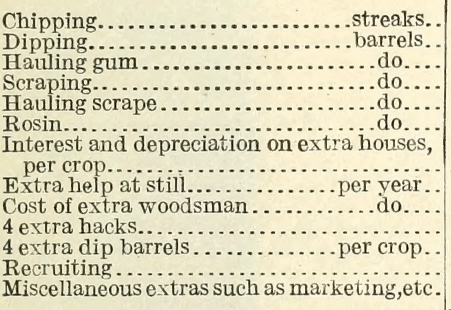 & $\begin{array}{r}70 \\
334 \\
334 \\
149 \\
149 \\
298\end{array}$ & $\begin{array}{r}38 \\
248 \\
248 \\
90 \\
90 \\
220\end{array}$ & $\begin{array}{r}1 \$ 9.00 \\
2.40 \\
2.50 \\
2.40 \\
2.50 \\
2.75 \\
110.00 \\
2,000.00 \\
900.00 \\
.75 \\
2.00\end{array}$ & $\begin{array}{r}\$ 630.00 \\
133.60 \\
167.00 \\
59.60 \\
74.50 \\
223.50\end{array}$ & $\begin{array}{r}\$ 342.00 \\
99.20 \\
124.00 \\
36.00 \\
45.00 \\
165.00\end{array}$ & $\begin{array}{r}\$ 288.00 \\
34.40 \\
43.00 \\
23.60 \\
29.50 \\
58.50 \\
\\
28.60 \\
40.00 \\
18.00 \\
3.00 \\
10.00 \\
5.00 \\
50.00\end{array}$ \\
\hline Total........... & & & & & & 631.60 \\
\hline
\end{tabular}

1 Per streak.

2 Per barrel.

\section{SUMMARY.}

1. Double chipping produced, in the first year's operation, 31 per cent more turpentine and 36 per cent more rosin than standard chipping. The height of the face at the end of the season was approximately the same as that of the standard face.

2. The net gain from double chipping was about $\$ 450$ per crop.

3. Narrow chipping produced 17.5 per cent less turpentine and rosin than standard chipping; the faces were only one-half as high as the standard at the end of the season.

ADDITIONAL COPIES

OF THIS PUBLICATION MAY BE PROCURED FROM

THE SUPERINTENDENT OF DOCUMENTS

GOVERNMENT PRINTING OFFICE

WASHINGTON, D. C.

AT

5 CENTS PER COPY

WASHINGTON : GOVERNMENT PRINTING OFFICE : 1917 



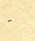


